\title{
Peningkatan Hasil Belajar IPA dan Berpikir Kritis Siswa Melalui Penerapan Pendekatan Kontekstual Model Inkuiri
}

\author{
Raras Wida Mustika* \\ Universitas Kristen Satya Wacana
}

A R T I C L E I N F O

Article history:

Received 30 January 2019

Received in revised form

10 February 2019

Accepted 10 April 2019

Available online 20 May 2019

Kata Kunci:

Pendekatan Kontesktual

model Inkuiri, Hasil

Belajar dan Kemampuan

Berpikir Kritis

Keywords:

The Contextual Approach

to the Inquiry model,

Learning Outcomes and

Critical Thinking Ability
A B S T R A K

Tujuan penelitian ini adalah untuk mengetahui peningkatan hasil belajar IPA dan berpikir kritis siswa melalui penerapan pendektan kontekstual model inkuri di kelas V SD Negeri Gilirejo Kecamatan Wonosegoro Kabupaten Boyolali Tahun 2018/2019. Jenis penelitian ini adalah penelitian tindakan kelas (PTK). Subjek penelitian ini adalah siswa kelas 5 SD Negri Gilirejo Kecamatan Wonosegoro Kabupaten Boyolali yang berjumlah 35 siswa. Teknik pengumpulan data ini menggunakan teknik tes dan teknik non tes. Instrumen penelitian dengan menggunakan butir soal dan lembar observasi. Teknik analisis yang digunakan adalah teknik deskriptif komparatif yakni membandingkan hasil belajar IPA dan kemampuan berfikir kritis berdasarkan ketuntasan belajar, skor minimal, skor maksimal dan skor rata-rata pra siklus, siklus 1 dan siklus 2. Hasil penelitian menunjukkan bahwa peningkatan hasil belajar dan berfikir kritis. Berbagai Pekerjaan dapat diupayakan melalui pendekatan kontekstual model inkuri siswa kelas 5 SD Negri Gilirejo Kecamatan Wonosegoro Kabupaten Boyolali tahun 2018-2019 sudah terbukti. Hal ini ditunjukkan oleh meningkatnya hasil belajar dan berpikir kritis dari pra siklus, siklus 1 ke siklus 2.

\section{A B S T R A C T}

The purpose of this study was to determine the increase in science learning outcomes and students' critical thinking through the application of the inkuri model contextual assessment in the fifth grade of Gilirejo State Elementary School in Wonosegoro Subdistrict Boyolali Regency in 2018/2019. This type of research is classroom action research (CAR). The subjects of this study were fifth grade students of SD Negri Gilirejo, Wonosegoro Subdistrict, Boyolali Regency, which numbered 35 students. This data collection technique uses test techniques and non-test techniques. The research instrument used items and observation sheets. The analysis technique used is a comparative descriptive technique that compares science learning outcomes and critical thinking skills based on learning completeness, minimum score, maximum score and pre-cycle average score, cycle 1 and cycle 2. The results of the study show that the improvement in learning outcomes and critical thinking . Various Jobs can be pursued through the inkuri model contextual approach of 5th grade students of SD Negri Gilirejo, Wonosegoro Subdistrict, Boyolali Regency in 2018-2019. This is indicated by the increase in learning outcomes and critical thinking from the pre cycle, cycle 1 to cycle 2. 


\section{Pendahuluan}

Salah satu ilmu pengetahuan yang dipelajari pada berbagai jenjang pendidikan adalah Ilmu Pengetahuan Alam (IPA). IPA adalah ilmu pengetahuan yang mempelajari alam dan gejala-gelajanya atas dasar unsur sikap, proses, produk, dan aplikasi yang mana keempat unsur tersebut merupakan satu kesatuan. Pembelajaran IPA di sekolah tidak serta merta lepas dari masalah, terdapat beberapa masalah yang muncul dari pelaksanaan pembelajaran IPA di sekolah. Berdasarkan hasil wawancara dan observasi di kelas V di SDN Gilirejo Kabupaten Boyolali, ada beberapa masalah yang timbul di sekolah tersebut. Berdasarkan pengamatan melalui observasi, studi dokumentasi dan wawancara, tampak terdapat rendahnya hasil belajar siswa dan berpikir kritis. Hal ini tampak dari keaktivan siswa dalam bertanya dan berinteraksi masih tergolong sangat minim. Sebagaian siswa belum mampu mencapai nilai KKM, yaitu nilai 65. Dilihat dari hasil ulangan harian, sebanyak 10 siswa mampu mencapai dan melampaui KKM, sementara 25 siswa tidak mampu mencapai KKM. Hal ini menunjukkan bahwa terdapat masalah hasil belajar dalam pembelajaran IPA. Ketika peneliti melakukan observasi didalam kelas, yang terjadi adalah siswa tidak berkonsentrasi terhadap penjelasan guru. Disamping itu ada beberapa siswa yang asik dengan sendiri.

Untuk menyelesaikan masalah rendahnya hasil belajar siswa pada SDN Gilirejo ini dapat menggunakan pendekatan kontekstual model Inquiry. Model inkuiri ini lebih mengaitkan dengan kehidupan sekitar atau dunia nyata. Menurut (Komalasari K. , 2010), pembelajaran kontekstual merupakan konsep belajar dan mengajar yang membantu guru mengaitkan materi yang diajarkannya dengan situasi dunia nyata siswa dan mendorong siswa membuat hubungan antara pengetahuan yang dimilikinya dengan penerapan dalam kehidupan merek. Hal ini menunjukan bahwa didalam pembelajaran kontekstual, siswa menemukan hubungan makna ide-ide abstrak dengan penerapan praktis di dalam konteks dunia nyata. Siswa menginternalisasi konsep melalui penemuan, penguatan, dan keterhubungan. Pembelajaran kontekstual menghendaki kerja dalam sebuah tim, baik di kelas, laboraturium, maupun ditempat yang lainnya. Jadi dapat disimpulkan bahwa pembelajar kontekstual adalah pendekatan pembelajaran yang mengaitkan antara materi yang dipelajari dengan kehidupan nyata siswa seharai-hari, baik dalam lingkungan keluarga, sekolah, masyarakat maupun wargan negara, dengan tujuan untuk menemukan materi tersebut bagi kehidupan sehari-hari.

Mengingat pentingnya proses pelaksanaan pembelajaran yang baik pada setiap mata pelajaran di sekolah terutama pada mata pelajaran IPA maka penelitian tentang cara untuk meningkatkan hasil belajar siswa khususnya di SDN Gilirejo Kecamatan Wonosegoro Kabupaten Boyolali peneliti melakukan penelitiaan lebih lanjut untuk menyelesaikan masalah pada kurangnya hasil belajar siswa dan berpikir kritis. Hal ini untuk meningkatkan hasil belajar dan berpikir kritis pada siswa supaya SDM khususnya di Indonesia ini meningkat. Adapun yang menjadi tujuan dalam penelitian ini adalah untuk meningkatkan hasil belajar IPA dan berpikir kritis pada siswa kelas V di SDN Gilirejo Kecamatan Wonosegoro Kabupaten Boyolali. Penelitian ini diharapkan memberikan manfaat kepada pembaca secara teori dan sebagai sumbangan ide-ide yang ada di dalam pendidikan.

\section{Metode}

Penelitian ini merupakan penelitian tindakan kelas PTK. Metode PTK yaitu penelitian tindakan yang dilakukan di kelas dengan tujuan memperbaiki atau meningkatkan mutu praktik pembelajaran (Arikunto, 2008). Penelitian ini dilakukan dalam 2 siklus, setiap siklus tersebut terdiri 4 tahapan yang meliputi perencanaan, pelaksanaan tindakan, observasi dan refleksi. Penelitian ini dilakukan di Kelas V SDN Gilirejo Kecamatan Wonosegoro Kabupaten Boyolali pada semester ganjil tahun ajaran 2018-2019. Subjek dalam penelitian ini berjumlah 35 orang yang terdiri dari 19 siswa laki-laki dan 16 siswa perempuan. Penelitian ini menggunakan teknik sampling yang berjenis teknik sampling jenuh. Hal ini berarti seluruh siswa menjadi sampel. Variabel independen pada penelitian ini adalah pendekatan pembelajaran CTL model Inkuiri dan variable dependennya adalah hasil belajar dan berpikir kritis. Teknik pengumpulan data yang digunakan dalam penelitian ini menggunakan teknik observasi dan tes. Instrument pengumpulan data telah diuji validitas dan reliabilitasnya, sehingga bisa dipastikan bahwa instrument yang digunakan valid dan reliable. Analisis data pada penelitian ini melalui empat tahapan yaitu: (1) Tahap pengumpulan data. (2) Melakukan analisis terhadap semua data yang telah dikumpulkan secara deskriptif. (3) Mengintepretasikan data yang telah dianalisis sesuai dengan landasan teori. (4) Selanjutnya tahap terakhir pengambilan kesimpulan data. 


\section{Hasil dan Pembahasan}

Kondisi prasiklus menunjukkan bahwa kemampuan berpikir kritis siswa dan hasil belajar siswa masih rendah. Berdasarkan pengamatan awal yang dilakukan peneliti terhadap seluruh siswa Kelas V SDN Gilirejo, masih banyak siswa yang kurang memiliki kemampuan berpikir kritis dalam mengikuti pelajaran IPA. Hal ini ditunjukkan dengan minimnya antusias siswa dalam belajar dan minimnya pertanyaan yang dilontarkan siswa kepada guru terkait dengan materi pembelajaran IPA. Hasil studi dokumentasi yang dilakukan terhadap hasil ulangan harian IPA pun menunjukkan bahwa hasil belajar IPA siswa Kelas V SDN Gilirejo dapat dikatakan rendah. Sebagian siswa belum mampu mencapai nilai KKM, yaitu nilai 65. Dilihat dari hasil ulangan harian, sebanyak 10 siswa mampu mencapai dan melampaui KKM, sementara 25 siswa tidak mampu mencapai KKM. Hal ini menunjukkan bahwa terdapat masalah hasil belajar dalam pembelajaran IPA.

Terjadi peningkatan hasil belajar siswa kelas V SDN Gilirejo Kecamatan Wonosegoro Kabupaten Boyolali mulai dari kondisi pra siklus, siklus pertama dan sampai siklus kedua. Peningkatan dari kondisi pra siklus hingga siklus pertama tampak dari jumlah siswa yang mampu mencapai dan melampaui KKM. Pada kondisi pra siklus, terdapat 10 siswa yang tidak mampu mencapai atau melampaui KKM setinggi 65, dan 25 orang siswa mampu mencapainya. Setelah tindakan pada siklus pertama dilakukan, jumlah siswa yang mampu mencapai atau melampaui KKM adalah 29 orang atau meningkat 4 orang lebih banyak, sehingga prosentase siswa yang mampu mencapai KKM menjadi 82,86\%, sedangkan yang belum mampu mencapai KKM sebanyak 6 orang atau jika diprosentasekan adalah sebesar 17,14\%.

Setelah siklus kedua dilaksanakan, tampak bahwa hasil belajar kembali mengalami peningkatan. Nilai terendah pada siklus pertama sebesar 52, naik menjadi 66 pada siklus kedua. Hal ini menunjukkan bahwa semua siswa mampu mencapai dan melampaui KKM yang hanya 65 . Nilai tertinggi juga naik dari 88 pada siklus pertama menjadi 90 pada siklus kedua. Peningkatan hasil belajar secara umum dapat dilihat dari kenaikan nilai rata-rata kelas dari 74,26 pada siklus yang pertama, meningkat menjadi 77, 89 pada siklus yang kedua. Ditinjau dari prosentase ketuntasan, model pembelajaran kontekstual tipe inkuiri ini juga terbukti cocok diterapkan. Pada siklus pertama, masih terdapat 6 orang $(17,14 \%)$ yang belum mampu mencapai nilai KKM, dan pada evaluasi akhir siklus kedua, semua siswa (100\%) telah mampu dan melampaui KKM. Hal ini berarti model pembelajaran kontekstual tipe inkuiri mampu meningkatkan ketuntasan belajar siswa hingga $17,14 \%$.

Hasil penelitian ini sekaligus menguatkan hasil peneltian lain yang menghasilkan simpulan bahwa model pembelajaran kontekstual mampu meningkatkan hasil belajar siswa. Penelitian-penelitian sebelumnya yang menghasilkan simpulan yang sama antara lain adalah penelitian yang dilakukan oleh Romelah pada tahun 2013, Rohani pada tahun 2014, dan Nur Hidayat Latif pada tahun 2011. Semua penelitian ini dilakukan terhadap siswa SD dan pada topik bahasan yang berhubungan dengan IPA. Hal ini sekaligus menegaskan bahwa model pembelajaran kontekstual tipe inkuiri ini tepat digunakan dalam pembelajaran IPA di sekolah dasar dan menguatkan teori bahwa model pembelajaran kontekstual benarbenar bermanfaat dalam meningkatkan aktivitas dan hasil belajar. Proses pembelajaran yang menggunakan model pembelajaran ini menjadi lebih bermakna dan riil. Model pembelajaran kontekstual tipe inkuiri juga digunakan dalam meningkatkan kemampuan berpikir kritis siswa.

Hasil penelitian menunjukkan bahwa telah terjadi peningkatan kemampuan berpikir kritis siswa kelas V SDN Gilirejo dari siklus pertama hingga siklus kedua. Sebelum dilakukan tindakan, kemampuan berpikir kritis siswa dapat dikatakan rendah. Hal ini dapat dilihat dari minimnya aktivitas siswa dalam pembelajaran yang mengindikasikan pemikiran kritis mereka. Salah satunya adalah kebiasaan bertanya yang tidak dimiliki siswa. Siswa sangat jarang bertanya kepada guru tentang materi pembelajaran. Minimnya pertanyaan ini tidak diimbangi dengan kemempuan mereka untuk menyelesaikan persoalan evaluasi yang nyatanya masih rendah, bahkan tidak mampu mencapai nilai KKM. Seharusnya siswa bertanya kepada guru jika mereka mengalami kesulitan dalam memahami materi pembelajaran.

Hasil pengukuran kemampuan berpikir kritis siswa kelas V SDN Gilirejo Kecamatan Wonosegoro Kabupaten Boyolali dalam pelajaran IPA yang menggunakan model pembelajaran kontekstual tipe inkuiri pada siklus pertama pertemuan pertama menunjukkan bahwa skor terendah adalah 12, skor tertinggi adalah 31 dan rerata skor adalah 20,31 dimana terdapat 4 siswa (11,43\%) dalam kategori kurang baik, 29 siswa $(82,86 \%)$ dalam kategori cukup baik dan 2 siswa $(5,71 \%)$ dalam kategori sangat baik kemampuan berpikir kritisnya. Pada pertemuan kedua menunjukkan bahwa skor terendah adalah 18, skor tertinggi adalah 32 dan rerata skor adalah 24,06 dimana tidak terdapat siswa dalam kategori kurang baik, 28 siswa $(80,00 \%)$ dalam kategori cukup baik dan 7 siswa $(20,00 \%)$ dalam kategori sangat baik. Peningkatan kemampuan berpikir kritis siswa dalam pembelajaran IPA di kelas V tampak dari meningkatnya skor hasil pengukuran kemampuan berpikir kritis siswa. Pada pertemuan pertama, siswa dengan kemampuan berpikir kritis kategori kurang baik sebanyak 4 orang $(11,43 \%)$ dan setelah dilakukan tindakan kembali 
menjadi tidak ada lagi siswa yang berkategori kemampuan berpikir kritisnya kurang baik.Siswa yang memiliki kemampuan berpikir kritis pada kategori cukup baik di pertemuan pertama sebanyak 29 siswa $(82,86 \%)$ dan yang ada pada kategori sangat banyak ada 2 siswa $(5,71 \%)$. Kemudian meningkat pada pertemuan kedua menjadi 28 orang yang berada pada kategori cukup baik menjadi 28 siswa (80,00\%) dan 7 siswa $(20,00 \%)$ dalam kategori sangat baik. Rata-rata skor kemampuan berpikir kritis siswa pada pertemuan pertama adalah 20,31 dan meningkat pada pertemuan kedua menjadi 24,06 atau ada peningkatan skor rata-rata kemampuan berpikir kritis siswa sebesar 3,75. Hal ini menunjukkan bahwa model pembelajaran kontekstual tipe inkuiri mampu meningkatkan kemampuan berpikir kritis siswa kelas V dalam pembelajaran IPA.

Peningkatan kemampuan berpikir kritis siswa pada siklus yang pertama dirasa belum maksimal karena sebagian besar siswa masih berada pada kategori cukup baik, dengan demikian hal inilah yang melatarbelakangi dilaksanakannya siklus kedua. Setelah siklus kedua dilaksanakan, tampak bahwa tindakan berupa pembelajaran menggunakan model kontekstual tipe inkuiri ini mampu meningkatkan kemampuan berpikir kritis siswa kelas V SDN Gilirejo Kecamatan Wonosegoro Kabupaten Boyolali. Skor terendah pada akhir siklus pertama adalah 18, kemudian menjadi 21 pada akhir pertemuan pertama siklus kedua dan menjadi 22 pada akhir pertemuan kedua siklus kedua. Nilai tertinggi pada akhir siklus pertama adalah 32, kemudian pada akhir pertemuan pertama siklus kedua tetap pada angka 32, kemudian meningkat menjadi 36 pada akhir siklus kedua. Secara rata-rata, skor pada akhir siklus pertama adalah 24,06, kemudian meningkat pada pertemuan perta asiklus kedua menjadi 29,54 dan meningkat kembali pada akhir siklus kedua menjadi 30,54. Hal ini berarti peningkatan rata-rata skor kemampuan berpikir kritis siswa kelas V SDN Gilirejo Kecamatan Wonosegoro Kabupaten Boyolali dari akhir siklus pertama ke pertemuan pertama siklus kedua sebesar 5,48 dan peningkatan skor rata-rata dari pertemuan pertama ke pertemuan kedua pada siklus kedua adalah sebesar 1,00. Hal ini menunjukkan bahwa dengan menggunakan model pembelajaran kontekstual tipe inkuiri, kemampuan berpikir kritis siswa kelas V SDN Gilirejo Kecamatan Wonosegoro Kabupaten Boyolali dapat ditingkatkan dalam konteks mempelajari materi IPA, tentang tumbuhan hijau.

Hasil penelitian yang dilakukan ini sekaligus menguatkan bahwa model pembelajaran kontekstual benar-benar bermanfaat dalam meningkatkan aktivitas dan kemampuan berpikir kritis siswa. Proses pembelajaran yang menggunakan model pembelajaran ini menjadi lebih bermakna dan riil. Siswa dituntut agar dapat menangkap hubungan antara pengalaman dalam belajar disekolah dengan kehidupan nyata. Model pembelajaran kontekstual menganut aliran konstruktivisme, yaitu seorang siswa dituntut untuk menemukan pengetahuannya sendiri. Pembelajaran yang menggunakan metode pembelajaran kontekstual menjadi lebih bermakna dibandingkan dengan metode yang lainnya. Proses pembelajaran kontekstual yang melibatkan siswa secara aktif inilah yang membuat siswa menjadi lebih berpikir dan menggunakan kemampuan perpikir kritisnya dalam menghadapi segala sesuatu yang ada di lingkungan pembelajarannya. Dengan lebih digunakannya pemikiran siswa untuk menemukan pengetahuan sendiri, maka secara otomatis kemampuan berpikir kritis mereka juga akan meningkat.

\section{Simpulan Dan Saran}

Berdasarkan hasil penelitian dan pembehasan yang telah diuraikan, maka dapat disimpulkan bahwa model pembelajaran kontekstual tipe inkuiri mampu meningkatkan hasil belajar dan kemampuan berpikir kritis siswa kelas V SDN Gilirejo Kecamatan Wonosegoro Kabupaten Boyolali. Hal ini dibuktikan dengan peningkatan nilai rata-rata siswa dari siklus pertama ke siklus kedua, yaitu dari 74,26 menjadi 77,89. Selain itu, jumlah siswa yang mampu mencapai KKM juga meningkat. Pada kondisi pra siklus, hanya 10 dari 35 siswa yang mempu mencapai KKM, kemudian meningkat menjadi 29 dari 35 siswa dan meningkat kembali menjadi 35 dari 35 siswa (100\%) pada akhir siklus kedua. Hasil pengukuran kemampuan berpikir kritis siswa kelas V SDN Gilirejo Kecamatan Wonosegoro Kabupaten Boyolali juga menunjukkan peningkatan dari siklus pertama ke siklus kedua. Skor rata-rata pada siklus pertama mencapai 24,06 dan meningkat pada siklus kedua menjadi 30,54. Pada siklus pertama, masih terdapat siswa yang kurang dengan hasil belajar dan berpikir kritis, siswa yang memiliki kemampuan berpikir kritis dalam kategori cukup baik masih dominan, tetapi setelah siklus kedua siswa menjadi dominan pada kategori sangat baik.

Terdapat 3 saran yang dapat dirumuskan berdasarkan hasil penelitian ini, antara lain sebagai berikut: (1) Guru sebaiknya menggunakan model pembelajaran kontekstual dalam berbagai tipe yang sesuai dengan karakteristik siswa, masalah yang terjadi dalam pembelajaran, materi pembelajaran dan tujuan pembelajaran yang telah ditetapkan. (2) Lembaga pendidikan, yang dalam hal ini sekolah, harus menyediakan fasilitas baik sarana maupun prasaran yang ditujukan untuk mendukung terlaksananya pembelajaran yang mampu mengaktifkan siswa, kreatif, efektif mencapai tujuan pembelajaran dan 
menyenangkan bagi siswa. (3) Peneliti-peneliti berikutnya perlu melakukan penelitian tentang efektifitas model pembelajaran kontekstual pada mata pelajaran selain IPA.

\section{Daftar Rujukan}

Afcariono, Muchamad. "Penerapan pembelajaran berbasis masalah untuk meningkatkan kemampuan berpikir siswa pada mata pelajaran biologi." Jurnal Pendidikan Inovatif 3.2 (2008): 65-68.

Amin, Saiful. "Pengaruh model pembelajaran problem based learning terhadap kemampuan berpikir kritis dan hasil belajar geografi." JPG (Jurnal Pendidikan Geografi) 4.3 (2017): 25-36.

Arikunto. (2008). Penelitian Tindakan Kelas. Jakarta: Bumi Askara.

Ariyati, Eka. "Pembelajaran berbasis praktikum untuk meningkatkan kemampuan berpikir kritis mahasiswa." Jurnal Matematika dan IPA 1.2 (2010): 2-5.

Choize. (2018, April 18). Pengertian Skala Likert dan Contoh Cara Hitung Kuesionernya. Retrieved from diedit.com: https://www.diedit.com/skala-likert/

Dewi, K., W. Sadia, and N. P. Ristiati. "Pengembangan perangkat pembelajaran ipa terpadu dengan setting inkuiri terbimbing untuk meningkatkan pemahaman konsep dan kinerja ilmiah siswa." Jurnal Pendidikan dan Pembelajaran IPA Indonesia 3.1 (2013)

Dwijananti, Pratiwi, and D. Yulianti. "Pengembangan kemampuan berpikir kritis mahasiswa melalui pembelajaran problem based instruction pada mata kuliah fisika lingkungan." Jurnal Pendidikan Fisika Indonesia 6.2 (2010).

Fakhriyah, F. "Penerapan Problem Based Learning dalam Upaya Mengembangkan Kemampuan Berpikir Kritis Mahasiswa." Jurnal Pendidikan IPA Indonesia 3.1 (2014).

Fitriyani, Riski, Aloysius Duran Corebima, and Ibrohim Ibrohim. "Pengaruh Strategi Pembelajaran Problem Based Learning dan Inkuiri Terbimbing Terhadap Keterampilan Metakognitif, Berpikir Kritis, dan Hasil Belajar Kognitif Siswa SMA." Jurnal Pendidikan Sains 3.4 (2015): 186-200.

Hasnunidah, Neni. "Keterampilan Berpikir Kritis Siswa SMP Pada Pembelajaran Ekosistem Berbasis Konstruktivisme Menggunakan Media Maket." Jurnal Pendidikan MIPA 13.1 (2012): 64-74.

Jufri, Wahab, and Dwi Sulistyo Dj. "Efektivitas pembelajaran sains berbasis inkuiri dengan strategi kooperatif dalam meningkatkan keterampilan berpikir siswa SMP." Jurnal Pendidikan dan Pembelajaran (JPP) 17.2 (2010): 159-165.

Komalasari, K. (2010). Pembelajaran Kontekstual. Bandung: PT Refika Aditama.

Kono, Rahmad, H. Mamu, and L. Tangge. "Pengaruh Model Problem Based Learning (PBL) Terhadap Pemahaman Konsep Biologi Dan Keterampilan Berpikir Kritis Siswa Tentang Ekosistem Dan Lingkungan Di Kelas X SMA Negeri 1 Sigi." Jurnal Sains dan Teknologi Tadulako 5.1 (2016): 28-38.

Kurikulum, P. (2007). Pengembaangan Kurikulum pendidikan Tekhnoligi dan Kejuruan. Jakarta: Pusat Kurikulum dan Perbukuan Kemendikbud.

Kusumaningtias, Anyta, Siti Zubaidah, and Sri Endah Indriwati. "Pengaruh problem based learning dipadu strategi numbered heads together terhadap kemampuan metakognitif, berpikir kritis, dan kognitif biologi." Jurnal Penelitian Kependidikan 23.1 (2013): 33-47. 
Listiana, Lina. "Pemberdayaan Keterampilan Berpikir dalam Pembelajaran Biologi melalui Model Kooperatif Tipe GI (Group Investigation) dan TTW (Think, Talk, Write)." Proceeding Biology Education Conference: Biology, Science, Enviromental, and Learning. Vol. 10. No. 1. 2013.

Maftukhin, M. (2013). Skripsi: Keefektifan model pembelajaran CPS berbantuan CD pembelajaran terhadap kemampuan berpikir kritis materi pokok geometri kelas X. Semarang: Universitas Negeri Semarang.

Mariana, I., \& P., W. (2009). Hakikat IPA dan Pendidikan IPA. Bandung: PPPPTK IPA.

Mintania, Fesy, Muhammad Su'aidy, and I. Wayan Dasna. "Penerapan metode inkuiri terbimbing untuk meningkatkan hasil belajar dan sikap ilmiah siswa kelas XI IPA semester II SMA Negeri 5 Malang pada materi pokok koloid." SKRIPSI Jurusan Kimia-Fakultas MIPA UM (2013).

Mulyani, H. R. A. "Pengaruh Penerapan Pembelajaran Kontekstual Terhadap Peningkatan Penguasaan Konsep Bahan Kimia Dalam Kehidupan Sehari-hari dan Keterampilan Berpikir Kritis Siswa Kelas VIII SMP Negeri 4 Metro." Jurnal Bioedukasi 4.2 (2013): 114-121.

Nasution. (1992). Metode Penelitian Naturalistik Kualitatif . Bandung: Penerbit Tarsito.

Neka, I. Ketut, AAI Ngurah Marhaeni, and I. Wayan Suastra. "Pengaruh Model Pembelajaran Inkuiri Terbimbing Berbasis Lingkungan Terhadap Keterampilan Berpikir Kreatif Dan Penguasaan Konsep IPA Kelas V SD Gugus Viii Kecamatan Abang." PENDASI: Jurnal Pendidikan Dasar Indonesia 5.1 (2015).

Nurgiyantoro, B. (2008). Dasar-dasar Pengembangan Kurikulum Sekolah. Yogyakarta: BPFE.

Nurhadi. (2002). Pendekatan Kontekstual. Jakarta: Departemen Pendidikan Nasional, Dirjendikdasmen.

Nurhidayati, Siti, Siti Zubaidah, and Sri Endah Indriwati. "Pengaruh Metode Inkuiri Terbimbing Terhadap aktivitas Dan Hasil Belajar Biologi Siswa." Jurnal Kependidikan 14.3 (2015): 285-294.

Pratiwi, Yenni Putri. "Pengaruh Model Problem Based Learning terhadap Kemampuan Berpikir Kritis dan Berpikir Kreatif Siswa pada Pembelajaran Biologi." Skripsi, Universitas Sebelas Maret (2012).

Sanjaya, W. (2006). Strategi Pembelajaran Berorientasi Standar Proses Pendidikan. Bandung : Kencana Media Pradan Group .

Siswanto, Joko, and Abdul Wakhid Mustofa. "Pengaruh Penggunaan Model Pembelajaran Kontekstual Dengan Media Audio-Visual Terhadap Kemampuan Berpikir Kritis Dan Kreatif Siswa." Media Penelitian Pendidikan 6.1 (2012): 1-9.

Slameto. (2003). Belajar dan Faktor yang Mempengaruhi . Jakarta: Renika Cipta.

Subagyo, Y., and P. Marwoto. "Pembelajaran dengan pendekatan keterampilan proses sains untuk meningkatkan penguasaan konsep suhu dan pemuaian." Jurnal Pendidikan Fisika Indonesia 5.1 (2009).

Sumantri, J. P. (1999). Strategi Mengajar. Jakarta : Depdikbud Dirjen Dikti.

Taufiq, M., N. R. Dewi, and A. Widiyatmoko. "Pengembangan Media Pembelajaran IPA Terpadu Berkarakter Peduli Lingkungan Tema "Konservasi" Berpendekatan Science-Edutainment." Jurnal Pendidikan IPA Indonesia 3.2 (2014). 
Zubaidah, Siti. "Berpikir Kritis: Kemampuan Berpikir Tingkat Tinggi yang Dapat Dikembangkan melalui Pembelajaran Sains." Makalah Seminar Nasional Sains dengan Tema Optimalisasi Sains untuk memberdayakan Manusia. Pascasarjana Unesa. Vol. 16. 2010. 